\title{
Factors affecting the satisfaction of importers and exporters on e-tax payment procedures at Ho Chi Minh City's customs department
}

Factores que afectan la satisfacccion de los importadores y exportadores con los procedeminetos de pago de impuestos electronicos en el departamento de aduanas de la Ciudad de Ho Chi Minh, Vietnam

\author{
Perfecto G. Aquino*11, Revenio C. Jalagat ${ }^{2}$, Doan Hong Le ${ }^{1}$, \\ Hoang Thi Thanh $\mathrm{Ha}^{3}$ \\ ${ }^{1}$ Duy Than University, Vietnam \\ ${ }^{2} \mathrm{Al}$ Zahra College for Women, Oman \\ ${ }^{3}$ The Customs Department of Ho Chi Minh, Vietnam
}

Received March 3, 2019; accepted February 11, 2020

Available online February 18, 2020

\begin{abstract}
The dramatic impact of E-commerce being the trend insofar as modern governance and management operations of most service agencies and entitites in most countries which in effect hastens the delivery of services for local and international clientele-customers. This study focuses on the service delivery in VietNam with the launching of its electronic tax payments both for its exporters and importers taking place in Ho Chi Minh City VietNam.

This study analyzes the factors affecting the satisfaction of importers and exporters on the quality of electronic tax payment services at the HCM city Customs Department, through the survey of 347 enterprises participating in electronic tax payment services. Research results show that there are 6 factors that affect the satisfaction of enterprises on the quality of electronic tax payment service: Trust; Sympathy; Service capabilities; Tangible Media; Transparency and Coordinate Implementation. In particular, Trust

* Corresponding author.

E-mail address: jesusper186@gmail.com (P.G. Aquino).

Peer Review under the responsibility of Universidad Nacional Autónoma de México.


has the strongest impact and Transparency has the lowest impact. Key recommendations suggest that actions and plans for improvement should be undertaken taking into consideration the above-mentioned six factors in delivering its E-Tax Payment system to stakeholders.

JEL code: $\mathrm{M} 1, \mathrm{M} 10, \mathrm{H} 2 \mathrm{O}$

Keywords: Satisfaction; Service quality; Tariff; E-tax; Enterprises

\section{Resumen}

El impacto dramatico del comercio electronico es la tendencia en la mdedida en que la gobernanza y las operaciones de gestion modernas de la mayoria de las agencias y entidades de servicios en la mayoraria de los paises aceleran la prestaction de servicios para clients locales e internacionales. Este studio se centra en la prestacion de servicios en Vietnam con el lanzamiento de sus pagos de impuestos electronicos tanto para sus exportadores como para sus importadores que tienen lugar en la ciudad de Ho Chi Minh, Vietnam.

Este studio analiza los factores que afectan la satisfaciccion de los importadores y exportadores sobre la calidad de los servicios de pago electronico de impuestos en el Departamento de Aduanas de la ciudad de HCM, a traves de la encuesta a 347 empresas que participant en los servicios de pago electronico de impustos. Los resultados de la investigacion muestran que hay 6 factores que afectn la satisfaccion de las empresas sobre la calidad del servicio de pago electronico de impuestos: Confianza; Simpatia; Capacidades de servicio; Medios tangibles; Transparencia e implementacion coordinada. En particular, la confianza tiene el impacto mas fuerte y la tranparencia tiene el impacto mas bajo. Las recomendaciones y los planes de mejora deben tomarse en consideracion los seis factores antes mencionados al entregar su Sistema de pago de impuestos electronicos a las partes interesadas.

Código JEL: M1, M10, H2O

Palabras clave: Satisfaccion; Calidad del servicio; Tarifa; E-tax; Empresas

\section{Introduction}

The commodity economy has been developed along with the emergence of the state. Along with the emergence of the State is the birth of tax as a result of society's necessity. The state uses tax as a tool to financially perform its functions and tasks. Through taxes, the state uses the inherent political power for the accumulation of social wealth. In the structure of the tax system in each country, export and import taxes are one of the important taxes, a source of 
national budget incentives and a tool to regulate domestic production, as well as a lever for domestic economic development and international trade development. Along with the development of the national history, the tax system, the form of taxation and tax laws diversify and enable the region with the development of market economy, the citizens' contribution to the State are determined and publicly regulated by the laws of the State (Whalley, 2002).

For foreign trade activities, one of the most important taxes that is often referred to is the import / export tax, or the tariff (Whalley, 2002). Previously, Vietnam and many countries around the world have applied import tax as one of the effective measures to restrict trade and protect the domestic market. However, in the current trend of globalization and international economic integration, tariff and non-tariff barriers are gradually loosened and eliminated in line with the agreed schedule of commitments between Vietnam and member countries of international organizations and associations.Vietnam has become an official member of many regional and global economic links such as the Association of Southeast Asian Nations, ASEAN. Asia-Pacific Economic Cooperation Forum, APEC. World Trade Organization, WTO. signing the ASEAN Plus Agreements, participating in negotiating the Strategic Partnership Agreement, TPP), Vietnam is gradually cutting import and export taxes (Thanh, 2015). However, import and export taxes are still used by the state as a tool in trade policy for two reasons. Firstly, import and export tariffs are the only tool that the WTO allows for use due to its transparency and ease of use. Secondly, the import and export tax has been maintained and promoted as important as before. Especially, for developing countries such as Vietnam, import and export taxes contribute relatively large proportion of total state budget revenues. Specifically, according to data of the General Statistics Office, in the period from 2009 to 2013, revenue from import tax each year accounts for about 25-30\% of total state budget revenue. With a large proportion of this, the task of managing this source of revenue is a big challenge for relevant authorities, especially Customs (General Statistics Office of Vietnam, 2015).

Besides, in order to meet the requirements of reform and simplification of administrative procedures under Project 30 of the Government, the regulations on administrative procedures in the management of export tax and import tax must be further reformed, along with the creation of legal basis for the modernization of tax administration such as electronic tax declaration, e-customs. At the same time, the practice of Vietnam in Exports and Imports in recent years have also changed. The quantity of export and import goods increased rapidly, the demand for export and import of goods in various forms have been diversified. This entails the management of export and import goods that need to be changed to fit the reality (OEC, 2017).

The reform of the tax system for the period 2011-2020 has been approved by the Prime Minister, Resolution 36a / NQ-CP on e-Government and Decision of the Ministry of Finance on the tax administration reform in 2016 - 2020. In particular, Ho Chi Minh City Tax Department is trying to implement a comprehensive modernization program and has deployed 
electronic tax services, gradually modernizing the tax management including management methods. Especially, the application of information technology to tax administration and taxpayer support is one of the key tasks of the tax branch in general and the Tax Department of Ho Chi Minh City in particular. E-tax payments can be made 24/7, including holidays, festival and any place where internet access is available, while the usual method of paying taxes which is to pay tax directly at the point of collection (State Treasury or bank counters) are only available during working days and during working hours; clearly, paying electronic taxes helps businesses save time and travel costs, save time for transaction, simplify paperwork; entreprises are supported the information available in the tax database system, helped to setup information quickly, accurately and reduce errors.

However; the main challenge with this administrative tax reform is built on assessing the level of satisfaction by export and import enterprises considering the limitation as mentioned like non-availability of the service during weekends and holidays, ability of the employees to run and manage the system, and, the quality of service provision by the workforce in aherence to E-Tax Payment procedures and the delivery of such services. Within the four-year implantation target from 2016-2020, rigid monitoring and compliance must have been instituted to ensure the smooth implementation and transition throughout this period. In response to this challenge, this study is framed to assess the level of satisfaction in the utilization of E-Tax Payment by importer and exporter enterprises particularly in Ho Chi Minh City through identification of the factors that influence satisfaction.

\section{Research Objectives}

From the research problem, the following are the sets of objectives formulated:

1. To determine if trust significantly affects the satisfaction of import-export enterprises.

2. To determine the significant effect of responsiveness on the satisfaction of import-export enterprises?

3. To determine the significant effect of sympathy on the satisfaction of import-export enterprises.

4. To determine if service capabilities significantly affect the satisfaction of customers of import-export enterprises. 
5. To determine the significant effect of tangible media on the satisfaction of the customers of import-export enterprises.

6. To determine the significant effect of the transparency on the satisfaction of import-export enterprises.

7. To determine the significant effect of coordinate implementation on the satisfaction of import-export enterprises.

\section{Research Questions}

The main objective of this study is to determine the factors that influence the satisfaction of Importers and Exporters in Ho Chi Minh City's Customs Department, Vietnam. Specifically, it would like to seek answers to the following questions:

8. Does the service quality component of trust affect the satisfaction of import-export enterprises?

9. Does the service quality component of responsiveness affect the satisfaction of import-export enterprises?

10. Does the service quality component of sympathy affect the satisfaction of import-export enterprises?

11. Is there an effect of service capabilities on the satisfaction of import-export enterprises?

12. Is there an effect of tangible media on the satisfaction of import-export enterprises?

13. Is there an effect of transparency on the satisfaction of import-export enterprises?

14. Is there an effect of coordinate implementation on the satisfaction of import-export enterprises? 


\section{Literature and Research Model Import and Export Tax}

Tax is a mandatory contribution that organizations and individuals' statutory rights and obligations to the State with specific levels and terms for the State to perform its functions and tasks. Export tax, import tax is an indirect tax, a component in the price of goods; Organizations and individuals that export or import goods subject to tax and fulfill their obligations and benefits to the State as prescribed by law. Import and export tax is an indirect tax on non-commercial and trade goods that are permitted to be exported or imported across the borders of Vietnam (Ho Ngoc Can, 2003). Export tax and import tax are an important part of a comprehensive macroeconomic, financial and economic economic policy system that is closely linked to a country's export-import management system and foreign policy.

\section{Public Electronic Services}

As defined by the World Bank (2015, p. 65), "E-government is the application of electronic services based on information technology (IT) - communication of government agencies in a systematic way to interact with citizens, businesses and social organizations. E-government is the use of the Internet and the world-wide network to provide information and government services to citizens. Gartner's definition of e-government is "the continuous optimization of service delivery, electoral participation and management by changing internal and external relationships through technology, the Internet and new vehicles" (Baum and Di Maio, 2000) as cited in the study of Jayashree \& Marthanda (2010, p. 2). E-Government is the name of a government system in which all state activities are transformed into a completely new concept; e-government is close to and convenient to citizens; advanced and modern technology. The use of E-Government enables better communication between government and citizens to ensure transparency, openness, convenience, mutual control and supervision between the citizen and the government; a government of the people, for the people and for the prosperity of the country in an environment of globalization and international integration (Jayashree \& Marthanda, 2010).

Relatively, online public service is a concept that is formed when the government applies ICT in operations in order to promote the efficiency and quality of public services. Online public services are public administrative services and other government services provided to organizations and individuals in the network environment. According to Pham Quang Toan (2012), e-public services in the field of taxation is the application of information technology in the whole service to support taxpayers fulfill all obligations to declare and pay taxes. At the 
same time, electronically processing information processing transactions between tax authorities and relevant agencies such as: Treasury, banks, customs, business registration. Providing e-services in the field The tax is part of the e-Government development and implementation program and is identified by the taxation department as a key task in the coming period.

\section{Service Quality}

According to Gronroos (1984), there is a distinction between two types of service quality, technical quality, which is acceptable to the customer, the content of the service itself and the quality of the service. It aslo includes the time in which the service is provided. According to Zeithaml and Bitner (1996), service quality is an excellent service to customers. Parasuraman (1988) Quality of service is a comprehensive assessment of attitudes toward service excellence. On the other hand,Zeithaml, Parasuraman, and Malhotra (2000) define the quality of e-services as an effective way to purchase and distribute goods and services. Research by Santos (2003) stressed that, the quality of online services is determined by the customer's overall judgment and evaluation of the service delivery process in a virtual environment. Focus on the interaction between the customer and the website.

One of the earlier and popular theories on service quality is the SERVQUAL by Parasuraman et al. (1988) in their study titled "SERVQUAL: AMultiple-Item Scale for Measuring Consumer Perceptions of Service Quality. From the 10 preliminary dimensions, it was refined and reduced into five-factor or dimensions namely: reliability, assurance, tangibles, empathy, and responsiveness. Reliability is defined as the accurate performance of promised services while assurance encompasses the ability of employees to convey trust and confidence as well as their sense of courteousy and job knowledge. Tangibles mean the physical aspect of the service such as equipment, facilities, etc. Empathy is providing due care and personal attention to customers' needs, and responsiveness is the willingness to promptly address customer's needs. Nyeck, Morales, Ladhari, and Pons (2002) strongly argued that, SERVQUAL has been used by many researchers in various contexts and industries especially in education, healthcare, financial services, and banking institutions.

\section{The Relationship between Quality of Service and Satisfaction}

According to Parasuraman et al. (1988), service quality and customer satisfaction are two different but interrelated concepts. Quality of service is the most influencing factor (Cronin and Taylor, 1992). Some empirical evidence suggests that, quality of service and satisfaction 
coexist. Some of the fundamental differences are "causality" (Parasuraman et al., 1985, 1988; Cronin and Taylor, 1992). Specifically, the level of customer satisfaction is the result of the quality of service. Quality of service is an ideal standard for assessing customer satisfaction (Zeithaml, Bintner, \& Gremler, 2017). Quality of service is also defined as the extent to which a service meets the needs and expectations of customers (Wisniewski, 2001). Meanwhile, Tse \& Wilton (1988) define customer satisfaction as a response to the perceived sense of difference between expectation, expectation and service performance. In the public sector for example, Bovaird \& Loffler (2003) argue that high quality public administration not only increases customer satisfaction with public services, but also builds public trust in public governance. transparency, accountability, and through democratic dialogue. In the background of tax administrative services, taxpayers are customers and tax authorities are suppliers. The satisfaction of the taxpayers is a perception of the results obtained from the tax administration services provided by the tax authorities against their needs.

Generally, the quality of public services is understood as the perception of the public about state administrative procedures and the way in which they are guided, received and dealt with by public servants. In 1988, it can be remembered as previously mentioned the development of SERVQUAL scale by Parasuraman, et.al. (1988) with five (5) components to measure service quality based on the perception of the customers themselves. However; in 2005, Parasuraman modified the measurement of satisfaction through online service quality. The ES-QUAL model has been developed in seven dimensions: (1) Efficiency, (2) Satisfaction, (3) Availability of System, (4) Security, (5) Feedback, (6) Compensation, (7) Contact. Connolly (2007) 's study on the quality of web services provided by the IRS confirms the seven elements of the $\mathrm{E}-\mathrm{S}$ - QUAL model. The study of Abhichandani \& Horan (2006) on the satisfaction of citizens in using US government services has identified five factors: (1) Usefulness, (2) Reliability, (3) Effective, (4) Optional, (5) Flexibility. Conversely, the California Citizenship Acquisition (ACSI) measurement model in the United States indicates four components: (1) procedures, (2) information provided, (3) ) Customer Service and (4) Website Usability.

Today, meeting customer satisfaction is one of the essential elements of a quality management system because higher customer satisfaction leads to greater loyalty. Samadi \& Nazarian's (2013) research titled "Study and Measurement of Taxpayers Satisfaction: Case Study of the General Department of Taxation of Tehran" provides a model of measures of customer satisfaction measurement that includes the 5 Factors: (1) Taxpayer performance, (2) Customer expectations, (3) Process of implementation, (4) Legality and (5) Organizational regulations.

However; in this study, it utilized the Parasuraman scale to measure the level of satisfaction of taxpayers on the quality of advocacy services at the Tax Department of Kien Giang Province. Based on the theory of service quality, Son, Long, and Cuong (2013), quality of service assessment were done with the topic "The taxpayers' quality of supporting services at 
Kien Giang province Taxation Department" provides a model of seven components: tangible media; transparency; service capabilities; responsiveness; trust; transparency, coordinate implementation; and sympathy. The research results show that the level of satisfaction of taxpayers on the quality of advocacy services at Kien Giang Tax Department. From these research results, the article offers solutions to improve the quality of taxpayer service.

Using the data collected from the survey of 132 taxpayers' satisfaction survey on service quality of Na Hang district Tax Department, Tuyen Quang province. Research by Huong, Nha, and Duong (2015), "Taxpayers Satisfaction with the Quality of Service of the Tax Office of Na Hang District, Tuyen Quang Province" also identified seven factors affecting the level of satisfaction Tax payments include: (1) Credibility; (2) Facilities; (3) sympathy; (4) democracy and justice; (5) capacity to serve; (6) Publicity - transparency; (7) Level of response. The results of the regression analysis show that, among Factors affecting taxpayers satisfaction, the factor of trust is most important, followed by Facilities, Ownership and fairness, Responsiveness, Serviceability and, ultimately, Openness and Transparency.

\section{The Proposed Model}

Examining the actual research results of the previous topics, the author proposes factors that affect the satisfaction of importers and exporters of electronic tax collection procedures at the Customs Department of Ho Chi Minh City. These include: (1) Trust; (2) Responsiveness; (3) Sympathy; (4) Service Capabilities; (5) Tangible Media. In addition, the results of previous studies show that the field of fiscal administration, taxation is a public administrative service operating under the mandate of the State administrative apparatus, so transparency is not a factor. In this paper, the authors propose to use the (6) Transparency element in their research.

Under practical conditions, the (7) Coordinate Implementation factor in electronic tax collection and payment procedures is, on the overall level, the coordination of tax collection and collection by related parties: Export-Import-Commercial-Treasury The State-Customs, in view of the implementation at the Customs Department of Ho Chi Minh City, the status of electronic tax collection procedures meet the general objectives of ensuring the interests of both taxpayers, customs , commercial banks, treasury, etc., when applied specially bring many benefits to the business community import-export (taxpayers), simple procedures, convenient; minimum declaration information; Taxpayers can choose a variety of payment services provided by commercial banks such as ATMs, Internetbanking, Mobilebanking; Customs Sub-Departments pay tax on import and export goods as soon as they receive the data online from banks and at the same time clear customs clearance of goods. This reduces 
the costs incurred for importers and exporters, so the Coordination factor proposed by the authors in their research.

The basis of using these variables over other models of service quality largely depend on the nature and customized needs of the importer and exporter enterprises in Ho Chi Minh City. The E-tax payment system is considerably new to the users and thus, perceptions of its performance can be best measured as to whether the system can be trusted, responsive to the customer's needs, workers particularly the custom officers sympathize with the needs of importers and exporters. Further, service capabilities specifically pointed out the readiness of the department to serve the importers and exporters at its full strength coupled with tangible media or means to meet the physical needs of users which may include the facilities, equipments, and others. Since government activities are prone for corruptible activities and transaction, transparency is best utilized in this study as the department's ability to detect and counter illegal and corruptive activities through the online application and lastly, coordinate implementation which resembles team efforts and harmonized or united activities by all concerned workforce.

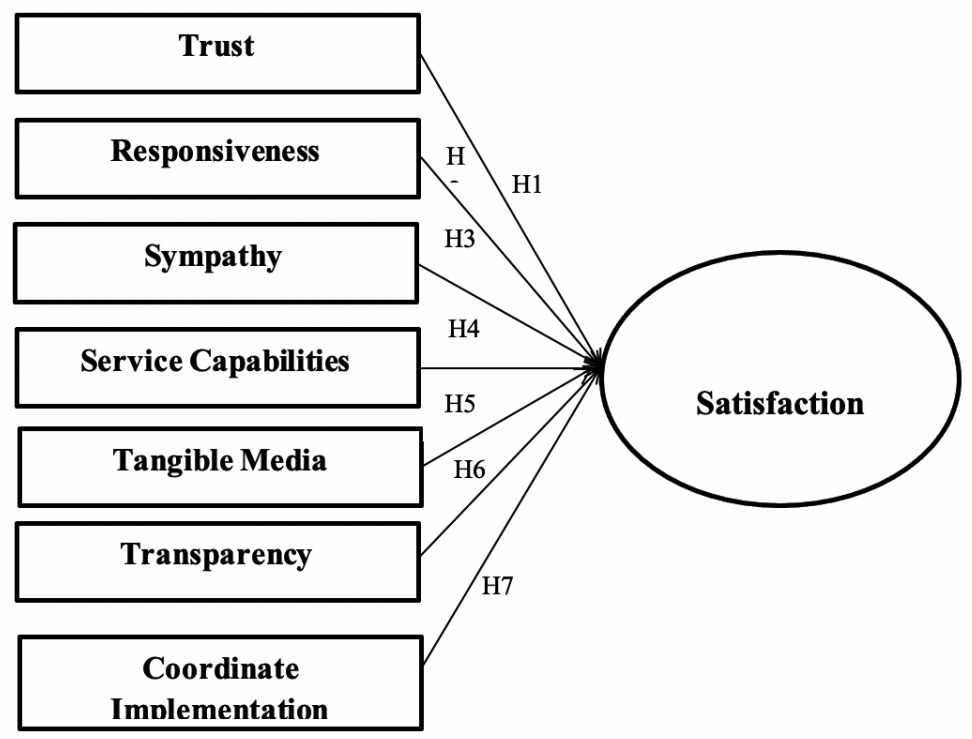

Figure. 1. The proposed research model 


\section{The Research Hypotheses}

Hypothesis H1: Trust factor has a positive effect (+) on the satisfaction of import-export enterprises.

Hypothesis $\mathrm{H} 2$ : The responsiveness factor has a positive effect (+) on the satisfaction of the import-export enterprise.

Hypothesis H3: The sympathy factor has a positive effect (+) on the satisfaction of import-export enterprises.

Hypothesis H4: Service Capabilities factor has a positive effect (+) on the satisfaction of the import-export enterprise.

Hypothesis H5: The Tangible Media factor has a positive effect (+) on the satisfaction of the importer and exporter.

Hypothesis H6: Transparency factor has a positive effect (+) on the satisfaction of import-export enterprises.

Hypothesis H7: Coordinate Implementation factor has a positive effect $(+)$ on the satisfaction of import-export enterprises.

\section{Research Methodology}

Initially, the author invited 5 customers representing import-export businesses in Ho Chi Minh City, 2 specialists of IT Department of General Department of Vietnam Custom and IT Department of Customs of HCM city, 5 staffs of Team of Import and Export Procedures of Customs Branch of SG port of zone 1; Customs Department of TSN Airport; Customs sub-department managing investment; Customs Department of SG Port of zone 3, Customs Department of Express Delivery and Deputy Director of Argibank Southern Saigon Branch, IT specialist of Viettinbank Eastern Saigon branch to discuss the outline Preliminary research is as follows:

Table 1

Distribution of Variables and its Codes

\begin{tabular}{lll}
\hline NUMBER & CONTENT & CODE \\
\hline I. Factor: Trust & & TC \\
\hline 1 & Customs officers shall strictly comply with the provisions on proce- & TC1 \\
& dures for electronic tax collection and payment and other relevant \\
& customs regulations.
\end{tabular}


Customs officers are always careful in business operations, not to TC2 generate errors.

3

Customs officers have good ethics, do not harass books causing dif- TC3

ficulties in the process of electronic tax collection and payment, not required to provide information, papers outside the regulations. collection procedures of customs officers. ic tax collection procedures.

\begin{tabular}{|c|c|c|}
\hline II. Factor: Responsive & ness & DU \\
\hline 1 & $\begin{array}{l}\text { Customs officers are friendly, courteous and courteous to the busi- } \\
\text { ness. }\end{array}$ & DU1 \\
\hline 2 & $\begin{array}{l}\text { Customs officers shall be arranged reasonably and in balance with } \\
\text { the request for settlement of procedures. }\end{array}$ & DU2 \\
\hline 3 & $\begin{array}{l}\text { Customs officers work professionally, support enterprises in time } \\
\text { problems. }\end{array}$ & DU3 \\
\hline 4 & Make sure the time for electronic tax collection is 5-7 minutes. & DU4 \\
\hline 5 & $\begin{array}{l}\text { Ensure promptly deducting debts for enterprises when receiving tax } \\
\text { paid messages at the e-payment gateways from commercial banks. }\end{array}$ & DU5 \\
\hline III. Factor: Sympathy & & $\mathrm{CT}$ \\
\hline 1 & $\begin{array}{l}\text { The customs office always exchanges and acquires and meets the } \\
\text { requirements of creating favorable conditions for the business com- } \\
\text { munity in electronic tax collection and payment procedures. }\end{array}$ & CT1 \\
\hline 2 & $\begin{array}{l}\text { Customs offices shall promptly propagate and disseminate changes } \\
\text { in regulations on electronic tax collection and payment to the busi- } \\
\text { ness community for implementation. }\end{array}$ & $\mathrm{CT} 2$ \\
\hline 3 & $\begin{array}{l}\text { The customs officer shall provide complete guidance on the proce- } \\
\text { dural steps for the enterprise and assist the enterprise in providing } \\
\text { relevant information so that the electronic tax declaration can be } \\
\text { accurately recorded. }\end{array}$ & СТ3 \\
\hline 4 & $\begin{array}{l}\text { Customs officers shall promptly handle cases arising when the } \\
\text { electronic payment gate system has technical problems affecting } \\
\text { the procedures for performing electronic tax payment and payment } \\
\text { procedures. }\end{array}$ & CT4 \\
\hline 5 & $\begin{array}{l}\text { The customs officer shall collect the problems and difficulties of the } \\
\text { enterprise paying electronic tax, and propose solutions to remedy } \\
\text { the situation. }\end{array}$ & CT5 \\
\hline
\end{tabular}




\begin{tabular}{|c|c|c|}
\hline \multicolumn{2}{|c|}{ IV. Factor: Service Capabilities } & \multirow{2}{*}{$\begin{array}{l}\text { NLPV } \\
\text { NLPV1 }\end{array}$} \\
\hline 1 & $\begin{array}{l}\text { Customs officers shall ensure their professional qualifications and } \\
\text { professional operations related to the handling of electronic tax col- } \\
\text { lection and payment procedures. }\end{array}$ & \\
\hline 2 & Customs officers are well aware of relevant regulations and policies. & NLPV2 \\
\hline 3 & $\begin{array}{l}\text { The officer shall promptly update the additional or new functions in } \\
\text { the exploitation and use of the electronic exchange, comparison and } \\
\text { supply system for the electronic tax collection and payment. }\end{array}$ & NLPV3 \\
\hline 4 & $\begin{array}{l}\text { Customs Departments and Sub-Departments shall ensure the im- } \\
\text { plementation and observance of regulations on responsibilities of } \\
\text { customs offices in the procedures for collecting and remitting elec- } \\
\text { tronic tax. }\end{array}$ & NLPV4 \\
\hline \multicolumn{2}{|c|}{ V. Factor: Tangible Media } & $\mathrm{HH}$ \\
\hline 1 & $\begin{array}{l}\text { Customs offices and sub-departments are equipped with modern } \\
\text { and synchronous IT systems to serve enterprises in electronic tax } \\
\text { payment procedures. }\end{array}$ & HH1 \\
\hline 2 & $\begin{array}{l}\text { The system provides stable power and can handle large power fail- } \\
\text { ures. }\end{array}$ & $\mathrm{HH} 2$ \\
\hline 3 & $\begin{array}{l}\text { They are equipped with public computers and provide WIFI for } \\
\text { businesses to look up the electronic tax returns of their declarations, } \\
\text { as well as to use online public services. }\end{array}$ & $\mathrm{HH} 3$ \\
\hline 4 & Electronic payment gateway is stable. & $\mathrm{HH} 4$ \\
\hline 5 & $\begin{array}{l}\text { Ensure the quality of the information transmission system for elec- } \\
\text { tronic tax collection in time } 24 / 7 \text {. }\end{array}$ & HH5 \\
\hline \multicolumn{2}{|c|}{ VI. Factor: Transparency } & MB \\
\hline 1 & The procedure for electronic tax collection is publicly listed. & MB1 \\
\hline 2 & $\begin{array}{l}\text { To publicly post up and fully and promptly update the list of com- } \\
\text { mercial banks participating in the program of coordinating state } \\
\text { budget revenues with the General Department of Customs. }\end{array}$ & MB2 \\
\hline 3 & $\begin{array}{l}\text { To promptly notify documents and time limits for the addition or } \\
\text { amendment of budget indexes related to state budget revenues for } \\
\text { import / export goods. }\end{array}$ & MB3 \\
\hline 4 & $\begin{array}{l}\text { To publicly list the lists and information of the Customs Officers } \\
\text { directly involved in the transaction with the commercial banks par- } \\
\text { ticipating in the revenue collection and the State Treasury. }\end{array}$ & MB4 \\
\hline
\end{tabular}




\begin{tabular}{|c|c|c|c|c|}
\hline \multicolumn{4}{|c|}{ VII. Factor: Coordinate Implementation } & PHTH \\
\hline 1 & \multicolumn{3}{|c|}{$\begin{array}{l}\text { Ensure strict implementation of regulations on exchange of infor- } \\
\text { mation on tax collection and payment related to import and export } \\
\text { activities at the GDT electronic payment gateway. }\end{array}$} & PHTH1 \\
\hline 2 & \multicolumn{3}{|c|}{$\begin{array}{l}\text { To ensure the coordination and coordinated work of customs offices } \\
\text { and commercial banks on the working time and responsibilities of } \\
\text { the involved parties when carrying out the procedures; }\end{array}$} & PHTH2 \\
\hline 3 & \multicolumn{3}{|c|}{$\begin{array}{l}\text { Ensure accuracy when transferring information collected tax pay- } \\
\text { ment from commercial banks to the customs. }\end{array}$} & PHTH3 \\
\hline \multicolumn{4}{|c|}{ VIII. Factor: Satisfaction } & $\mathrm{HL}$ \\
\hline 1 & \multicolumn{3}{|c|}{$\begin{array}{l}\text { The business is satisfied with the cooperation program between the } \\
\text { customs and commercial banks. }\end{array}$} & HL1 \\
\hline 2 & \multicolumn{3}{|c|}{$\begin{array}{l}\text { The business is satisfied with the results of electronic tax collection } \\
\text { at HCMC Customs Department. }\end{array}$} & HL2 \\
\hline 3 & \multicolumn{3}{|c|}{$\begin{array}{l}\text { Enterprises are satisfied with the current form of electronic tax col- } \\
\text { lection. }\end{array}$} & HL3 \\
\hline \multicolumn{5}{|c|}{ ENTERPRISE INFORMATION } \\
\hline \multirow[t]{3}{*}{1} & \multirow{3}{*}{$\begin{array}{l}\text { Enterprise } \\
\text { features }\end{array}$} & 1. & \multicolumn{2}{|c|}{ Enterprises with private capital $>50 \%(\mathrm{DNTN})$} \\
\hline & & 2. & \multicolumn{2}{|c|}{ Enterprises with State capital> 50\% (DNNN) } \\
\hline & & 3. & \multicolumn{2}{|l|}{ Foreign-invested enterprises. } \\
\hline \multirow[t]{4}{*}{2} & \multirow{4}{*}{$\begin{array}{l}\text { Field of } \\
\text { operation }\end{array}$} & 1. & Joint venture investment & \\
\hline & & 2. & Processing, producing, exporting & \\
\hline & & 3. & Import-export business & \\
\hline & & 4. & Other: & \\
\hline \multirow[t]{3}{*}{3} & \multirow{3}{*}{$\begin{array}{l}\text { Annual tax } \\
\text { amounts paid } \\
\text { to the State } \\
\text { budget }\end{array}$} & 1. & \multicolumn{2}{|l|}{ Under 50 billion } \\
\hline & & 2. & \multicolumn{2}{|l|}{ Between 50 and 100 billion VND } \\
\hline & & 3. & \multicolumn{2}{|l|}{ Over 100 billion } \\
\hline \multirow[t]{3}{*}{4} & \multirow{3}{*}{$\begin{array}{l}\text { Enterprises use } \\
\text { the form of tax } \\
\text { payment }\end{array}$} & 1. & \multicolumn{2}{|l|}{ Cash } \\
\hline & & 2. & \multicolumn{2}{|l|}{ Transfer } \\
\hline & & 3. & \multicolumn{2}{|l|}{ Cash and transfer } \\
\hline
\end{tabular}

Source: Developed by authors

Based on the results of the above scale building, a formal questionnaire and trial interviews were conducted. 50 clients were representatives of enterprises to carry out electronic tax collection procedures and to check whether the wordings of the questionniares are clear or 
not according to the understanding of the business. The results of the interviews show that enterprises fully understand the meaning of the items used in the official survey.

After the interview, formal interviews were conducted, to ensure the results in a linear regression analysis, the sample size needed to be at least $n>=8 m+50$ (n: minimum sample size, m: number of independent variables of the model) (Nguyen Dinh Tho, 2013), so with the study of the topic, the number of observations is about $8 * 34+50=322$ survey. In addition, with the larger sample size and the quality of the survey when collected, the author expected the number of questionnaires to be about 340 votes.

Subjects of survey are importing / exporting enterprises who participants of electronic tax payment procedures at the Customs Department of Ho Chi Minh City. First, survey via email: the author will send the survey by email hahtt970018@customs.gov.vn to the email address of the company to conduct interview. Secondly, direct surveys at 13 Customs Sub-Departments of Ho Chi Minh City.

\section{Research Results and Discussion}

Currently, the Customs Department of Ho Chi Minh City is one of 34 local customs units under GDVC. Since its inception, the Customs Department of Ho Chi Minh City, with an initial force of 54 people, has mainly been staffed by the Southern Economic and Finance Department and officials from the Central Customs Department to mobilize and take over the domain. So far, the Customs Department of Ho Chi Minh City has been staffed with 1966 CBCC with high level of education and professional qualifications. With 400 questionnaires distributed, the author collected 347 valid questionnaires $(86.8 \%)$ for inclusion in the data analysis.

Table 2

Summary Table Describing the Data

\begin{tabular}{cll}
\hline $\mathrm{n}=347$ & FREQUENCY & RATIO $(\%)$ \\
\hline Business features & 347 & 100 \\
Private enterprise & 165 & 47.6 \\
State enterprises & 93 & 26.8 \\
Foreign enterprises & 89 & 25.6 \\
Field of operation & 347 & 100 \\
Joint venture investment & 87 & 25.1 \\
Processing, manufacturing & 75 & 21.6 \\
Trading and exporting & 146 & 42.1 \\
Other & 39 & 11.2 \\
\hline
\end{tabular}




\begin{tabular}{cll}
\hline Annual amount of tax payment to State Budget & 347 & 100 \\
Under 50 billion & 226 & 65.1 \\
From 50 to 100 billion & 98 & 28.2 \\
Over 100 billion & 23 & 6.6 \\
\hline Form of tax payment & 347 & 100 \\
Cash & 17 & 4.9 \\
Transfer & 21 & 6.1 \\
Both forms & 309 & 89.0 \\
\hline
\end{tabular}

Source: Developed by authors

Key results in Table 2 show that, $47.6 \%(\mathrm{n}=165)$ belong to private enterprises and where the majority operate through trading and exporting with $42.1 \%(n=146)$. Furthermore, most of these enterprises have paid under 50 billion $(65.1 \%, \mathrm{n}=226)$ and prefer both forms of tax payment (Cash and Transfer) with 89\% ( $\mathrm{n}=309)$.

\section{Evaluation of the Cronbach's Alpha scale}

Scale of satisfaction of exporters and importers on the quality of electronic tax payment service at HCMC Customs Department. HCM consists of 7 factors with 34 variables of observation. The results of the Cronbach's alpha coefficient calibrated in Table 3 show that all scales have Cronbach's alpha reliability (greater than 0.6 or 0.7 ), and the correlation coefficient is greater than 0.3 (Griethuijsen et al., 2014).

Table 3

Evaluation of Cronbach's Alpha and Coefficient of Variables

\begin{tabular}{ccccc}
\hline Code & Variables & Number of variables & Cronbach's Alpha & Coefficient \\
\hline TC & Trust & 5 & 0.816 & 0.567 \\
DU & Responsiveness & 5 & 0.750 & 0.457 \\
CT & Sympathy & 5 & 0.842 & 0.613 \\
NLPV & Service Capabil- & 4 & 0.697 & 0.428 \\
& ities & & & \\
HH & Tangible Media & 5 & 0.791 & 0.545 \\
MB & Transparency & 4 & 0.674 & 0.391 \\
PHTH & Coordinate Imple- & 3 & 0.729 & 0.515 \\
& mentation & & &
\end{tabular}

Source: Developed by authors 


\section{Correlation Analysis and Multiple Regression Analysis}

There are 7 factors in the quality of the e-commerce service together with the satisfaction of enterprises which will be included in the correlation analysis and multiple linear regression.

The regression model was determined according to the adjusted study model:

$$
\mathrm{HL}=\beta 0+\beta 1 * \mathrm{TC}+\beta 2 * \mathrm{DU}+\beta 3 * \mathrm{CT}+\beta 4 * \mathrm{NLPV}+\beta 5 * \mathrm{HH}+\beta 6 * \mathrm{MB}+\beta 7 * \mathrm{PHTH}
$$

In which: HL - Dependent variable (Y): Satisfaction of business. Independent variables (Xi): Trust (TC), Responsiveness (DU), Sympathy (CT), Service Capabilities (NL), Tangible Media $(\mathrm{HH})$, Transparency (MB), and, Coordinate Implementation (PHTH). Pearson correlation matrix shows, value significance of the variables: TC, CT, HH, NLPV, MB, PHTH less than 0.05 which indicate that these variables are related to the dependent variable. In addition, the correlation coefficient between the independent variables are not large (less than 0.85) so it is likely that the independent variables are not correlated an which means that, there will be no hyperbolic phenomena. The significance value for DU variables greater than 0.05 , it is not sufficient to conclude that there is a relationship between the independent variable and the dependent variable, which will be confirmed by the results in linear regression analysis.

Further analysis using Anova variance showed that, the statistical value was $F=154,809$ calculated from the R-Square value of the full model, sig value. $=0.000$. This indicates that, it is safe to reject the hypothesis H0: is the set of independent variables not related to the dependent variable, and this means that the model is constructed in accordance with the data set. Overall, $\mathrm{F}=48,998$ with a value of sig $=0.000$, indicating that the regression model is consistent with the data set. The Durbin-Watson test results are within acceptable $1<\mathrm{d}=$ $1,850<3$; So we can conclude that there is no autocorrelation between the variables in the model. The coefficient VIF of the $<10$ variables demonstrates that there are no hyperbolic phenomena. Adjusted R square $=0.757$, indicating that $75.70 \%$ of the variance of the dependent variable was explained by independent variables, while $24.30 \%$ of the satisfaction of the business came from other factors. We find that $\mathrm{R}^{2}(0.757)$ is smaller than $\mathrm{R}^{2}(0.762)$, so it is safer to evaluate the suitability of the model, as it does not exaggerate the fit of the model.

Results of the regression coefficients for each component in the model showed that: DU factor was not statistically significant, ie, no effect on satisfaction with Sig value $>0.05(0.650)$. The model is statistically significant with Sig value. The TC, CT, NLPV, HH, MB, PHTH were very small $(\mathrm{Sig}<0.05)$. Normalized regression weight $(\mathrm{B})$ of the regression model is 
positive (+) in accordance with the original expectations hypothesis. Thus, the hypotheses H1, H3, H4, H5, H6, H7 in the study model are accepted. Results showed that TC was the most important factor influencing the dependent variable (Beta $=0.364), \mathrm{HH}$ was the second most important factor $($ Beta $=0.293)$, followed by PHTH $($ Beta $=0.219)$, followed by CT $($ Beta $=0.189)$, followed by NLPV $($ Beta $=0.118)$ and MB with the lowest importance for the dependent variable $($ Beta $=0.101)$.

$$
\mathrm{HL}=0.364 \mathrm{TC}+0.293 \mathrm{HH}+0.219 \mathrm{PHTH}+0.189 \mathrm{CT}+0.118 \mathrm{NLPV}+0.101 \mathrm{MB}-1.130 .
$$

Table 4

Regression analysis of Independent and Dependent Variables

\begin{tabular}{|c|c|c|c|c|c|c|c|}
\hline \multirow{2}{*}{ Model } & \multicolumn{2}{|c|}{$\begin{array}{l}\text { Unstandardized } \\
\text { Coefficients }\end{array}$} & \multirow{2}{*}{$\begin{array}{l}\text { Standardized } \\
\text { Coefficients }\end{array}$} & \multirow{2}{*}{ t-value } & \multirow{2}{*}{$\begin{array}{c}\text { Significant } \\
\text { Level }\end{array}$} & \multicolumn{2}{|c|}{ Multicollinearity } \\
\hline & B & $\begin{array}{c}\text { Standard } \\
\text { Error }\end{array}$ & & & & Toler & VIF \\
\hline Constant & -1.130 & .167 & & -6.747 & .000 & & \\
\hline TC & .364 & .043 & .337 & 8.529 & .000 & .450 & 2.223 \\
\hline DU & -.011 & .025 & -.013 & -.453 & .650 & .889 & 1.125 \\
\hline CT & .189 & .036 & .181 & 5.181 & .000 & .575 & 1.740 \\
\hline NLPV & .118 & .041 & .104 & 2.901 & .004 & .550 & 1.819 \\
\hline $\mathrm{HH}$ & .293 & .045 & .244 & 6.461 & .000 & .491 & 2.036 \\
\hline MB & .101 & .031 & .097 & 3.248 & .001 & .789 & 1.267 \\
\hline РHTH & .219 & .027 & .226 & 7.959 & .000 & .873 & 1.146 \\
\hline
\end{tabular}

Source: Calculated by Authors

Regarding the regression analysis and the conformity assessment of the model, the results of the empirical study show that: The satisfaction of the import-export enterprises with the procedures of collecting and paying electronically at the Customs Department of Ho Chi Minh City is only Influenced by 6 factors with 29 variables of observation, the factors in the model are positive and the importance of factors from high to low as follows: Reliability (Beta = 0.364), Medium Performance (Beta $=0.293$ ), Performance $($ Beta $=0.118)$, Transparency (Beta $=0.101)$. In theory, the results of this study are highly reliable when compared with the SERVQUAL service quality scale. And, the responsiveness factor does not affect the satisfaction 
of the firm. Factors are clear and statistically significant. It can be concluded that increasing the value of any of the six components increases the level of satisfaction of the enterprise. This is in line with previous research results and the author also answered the question: The impact of each factor on the satisfaction of enterprises on the quality of e-commerce services in Hai Duong Department of HCMC.

And the actual test results differ from the original proposed model. In this study, the meta-analysis was not statistically significant: In fact, previous studies, a meta-factor have had an impact on satisfaction while in this study, the answer is without prejudice to the satisfaction, the panel considered that for each of the different sectors the definition of service quality was different; and the level of responsiveness of the field is also different. In the previous studies of Dang Thanh Son et al. (2013), Dam Thi Huong et al. (2015), the study with taxpayers in terms of paying taxes differs from the area of study in paying electricity taxes. Therefore, the conditions of the facilities are different, the information technology equipment and the level of human resources only meet a certain part for the needs of taxpayers expectations. For this study, at the HCMC Customs Department, the facilities for electronic tax collection and payment, the IT system of the industry and the Customs Department of Ho Chi Minh City are all well equipped with modern sets, meeting $100 \%$ of the time requirements for electronic tax collection procedures within 5-7 minutes; ensure the accounting debt deduction right for import and export enterprises when receiving the message for paid taxes at the electronic payment gate (Paygate) and customs officers meet the capacity to handle work as well as professional ethics. Satisfaction of the business enterprises (Importers and Exporters) are generally good and are positively influenced by majority of the independent variables used in this study.

Finally, the results of the study also show the suitability in the context of the empirical study when the proposed factor in the coordinate implementation has had a significant impact on the realm of harmony. The acceptability of import-export businesses with the procedure of electronic tax collection indicate a favorable response at the Customs Department of Ho Chi Minh City.

\section{Conclusions}

The findings of this study has drawn many points for conclusion. Firstly, the model chosen has identified the independent variables that positively and significantly impacts satisfaction of importer and exporter enterprises with trust having the highest influence; followed by tangible media; then sympathy; service capabilities; and, transparency while responsiveness does not affect satisfaction. Conclusion can be drawn from these results that, for an effective E-Tax payment to take place, the element of trust should be developed between the Customs 
Department and the Importers and Exporters enterprises for smooth conduct of business transactions. This is also done through the department's employment of state-of-art and modern facilities built on the significant positive impact of tangible media on satisfaction of enterprises.

Customs in general and Ho Chi Minh City Customs in particular is found to be functioning under strong sense of Professionalism, Transparency, Effectiveness as they continuously strive for continuous improvement. Firstly, to complete and support the operation of information technology systems for electronic tax collection and payment, the system should be physically secured. The strong positive impact of tangible media is evident with the department's utilization of synchronize system equipment, synchronize data for stakeholders to access data smoothly. Physical improvement of the website interface as user friendly, easy to use, easier to remember, especially that the function supports automatic number display. Pay the state budget, sub-item on the payment paper. Added a function to link to the tax return website, electronic invoices. Develop and provide a database for enterprises to self-access and look up the status of their tax obligations to collate and feedback to the tax authorities the shortcomings.

Secondly, coordinate implementation and in collaboration with digital certificate vendors, commercial banks. Determining this is the extension arm of the tax authorities to introduce the newly upgraded functions, the utility brings as well as share the experience correcting problems and problems in the process of tax payment as the banks shall coordinate with the collecting agencies in collecting tax amounts in the form of bank transfer and transfer such information to the e-customs payment gate before issuing them and certifying the transfer of money amounts on the taxpayers to remedy the situation that, taxpayers are required to provide remittance receipts from banks in coordination with taxpayers. Banks are advised not to separate each transaction on the deposit paper, in order to overcome the situation of centralized accounting system of customs accounting twice data pay.

Thirdly, the significant impact of transparency on satisfaction enable the customs department to set up a mechanism to monitor and update the database system of exchange data, upgrade the centralized tax accounting system software to control the work of tax inspection of enterprises. Ensuring the confidentiality of data and information of taxpayers in the process of provision of e-procurement services, mode of transmission / receipt, reconciliation of electronic data; standard data exchange messages must be digitally signed and encrypted; shared categories; Criteria on security and related informatics techniques. To intensify the examination, examination and reconciliation of tax collection and payment data in order to detect errors and mistakes soon for timely handling.

Fourth, strengthen the propaganda procedures for electronic tax collection focusing on types of enterprises, limited companies are newly established companies through conferences, newspapers, radio and television channels. In addition, the tax authorities will also be equipped with informatics equipment at check-in areas for enterprises to check information. 
Fifthly, in response to the strong impact between service capabilities and satisfaction, internal training should be paid attention to improve professional capacity, also to improve the sense of professional ethics for customs officers is a factor that has a significant impact on the sense of execution. The tax law of the business and the possibility of their tax fraud, rotating and transferring personnel as an effective way to improve both redundancy and lack of opportunity, as well as opportunities for personnel to be trained in a variety of disciplines. Reward individuals who have good sense of service, set a good example to encourage the whole team. At the same time, it is appropriate sanctions to limit and deter negative behaviors.

Sixthly, the tax office has regular support for taxpayers but has not focused and has not publicly supported the information. So, regularly receive the exchange of information on the system of declaration and electronic tax collection and payment system of the General Department of Customs, promote the online exchange as well as direct dialogue with enterprises. Remove difficulties and obstacles of enterprises in electronic tax collection and customs clearance. It is necessary to develop and implement a centralized and online support system for online taxpayers, such as the deployment of centralized online support services, by setting up a complete database system to address the support requirements. Automated form submission or forwarding to tax officials to respond online via means such as email, automated messaging. There should be support manuals, video tutorials, instructions to fix errors posted on the website for businesses to correct themselves. Integrated tax declaration, tax payment and tax return on the same website to facilitate business.

\section{References}

Bovaird, T., \& Loeffler, E. (2003). Evaluating the Quality of Public Governance: Indicators, Models and Methodologies. International Review of Administrative Sciences - INT REV ADM SCI., 69(3), 313-328. https://doi. org/10.1177/0020852303693002

Cronin, J.J., \& Taylor, S.A. (1992). Measuring Service Quality: A Reexamination and Extension. Journal of Marketing, 56(3), 55-68. http://dx.doi.org/10.2307/1252296

Griethuijsen, R. A., et. al. (2014). Global patterns in students' views of science and interest in science. Research in Science Education, 45(4), 581-603. http://dx.doi.org/doi: 10.1007/s11165-014-9438-6

Gronroos, C. (1984). A Service Quality Model and its Marketing Implications. European Journal of Marketing, 18(4), 36-44. https://doi.org/10.1108/EUM0000000004784

Huong, D. T., Nha, D.T.H., Duong, P.B. (2015). Taxpayers Satisfaction for Quality of Service of Na Hang District Tax Department, Tuyen Quang Province. Journal of Science and Development, 13(1), 133-142.

Jayashree, S., \& Marthandan, G. (2010). Government to E-Government to E-Society. Journal of Applied Sciences, 10(19), 2205-2210. http://doi.org/10.3923/jas.2010.2205.2210

Nyeck, S. \& Morales, M. \& Ladhari, Riadh \& Pons, Frank. (2002). 10 years of service quality measurement: Reviewing the use of the SERVQUAL instrument. Cuadernos de Difusion, 7(13), 101-107.

Parasuraman, A., et. al. (1985). A conceptual model of service quality and its implications for future research. Journal of Marketing, 49(4), 41-50. http://doi.org/ 10.2307/1251430 
Parasuraman, A., Zeithaml, V.A., \& Berry, L.L. (1988). SERVQUAL: A multiple-item, scale for measuring consumer perception of service quality. Journal of Retailing, 64 (1), 12-40.

Samadi M., \& Nazarian, M. (2013). Study and Measurement of Taxpayers Satisfaction (Case Study of Tehran Central Taxation Office). Journal of Tax Research, 21(17), 125-150.

Santos, J. (2003). E-service quality: A model of virtual service quality dimensions. Managing Service Quality. 13. 233-246. http://doi.org/10.1108/09604520310476490.

Son, D.T., Long, L.K., \& Cuong, D.V. (2013). Assessment of taxpayers' satisfaction with the quality of advocacy services at the Taxation Department of Kien Giang Province. Can Tho, 25(2013), 17-23.

Thanh, V.T. (2015). Vietnam's Perspectives on Regional Economic Integration. Journal of Southeast Asian Economies 32(1), 106-124. http://doi.org/10.1355/ ae32-lf

Tse, D.K., \& Wilton, P.C. (1988). Model of Customer Satisfaction An Extension. Journal of Marketing Research, 25(2), 204-212.

Wisniewski, M. (2001). Using SERVQUAL to assess customer satisfaction with public sector services. Managing Service Quality: An International Journal, 11(6), 380-388. https://doi.org/10.1108/EUM000000006279

General Statistics Office of Vietnam. (2015). Statistical Yearbook of Vietnam. Hanoi: Statistical Publishing House.

Zeithaml, V. A., \& Bitner, M. J. (1996). Service Marketing. New York : McGraw-Hill.Inc.

Zeithaml, V.A., Bintner, M.J., \& Gremler, D. (2017). Marketing Services: Intergrating customer focus across firms. ( $7^{\text {th }}$ Ed.). Boston: McGraw-Hill.

OEC. (2017). Vietnam Exports, Imports, and Trade Partners. Available from: https://oec.world/en/resources/data/ (Consulted: 12/1/2019).

The World Bank (2015). Annual Report 2015. Available from: http://documents1.worldbank.org/curated/ en/261151468325237852/pdf/341470EDevelopment.pdf (Consulted: 28/1/2019).

Whalley, J. (2002). Taxes and Trade. Available from: http://www.worldbank.org/wbi/publicfinance/documents/taxpolicy/Whalley.pdf (Consulted: 10/1/2019).

Baum, C., \& Di Maio, A. (2000). Gartners four phases of e-government model. Available from: http://www.gartner. com/DisplayDocument?id=317292.

Zeithaml, V.A., Parasuraman, A. \& Malhotra, A. 2000. A conceptual framework for understanding eservice quality: Implications for future research and managerial practice. Marketing Science Institute (MSI), Working Paper, Report No. 00-115. Cambridge, MA: MSI. 